\title{
Do non-profit organisations offer better places to work? A longitudinal analysis of cross-sectoral staff mobility
}
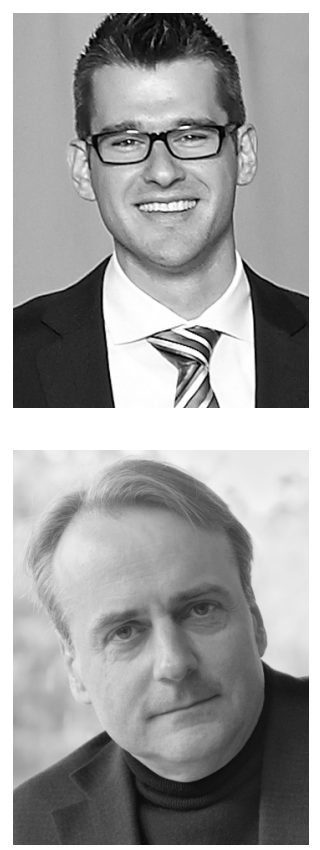

\section{Remo Aeschbacher \& Markus Gmür}

It is a widely held view that nonprofit organizations, due to their mission and value orientation, provide working conditions that are particularly motivating. Representative empirical evidence based on direct comparisons is rare to date. Longitudinal data on worker mobility from Switzerland is analysed to close the gap. In the framework of self-determination theory and the concept of public service motivation, the study examines how working for non-profit employers differs from working for for-profit and public employers. The analysis of employee data from the Swiss Household Panel shows that non-profit work prevails over for-profit and public work in aspects of self-determined motivation. Non-profit workers seem to be more interested in their tasks and report a higher job satisfaction level than their counterparts in the for-profit and public sectors. Most of the sectoral effects are also observed among the same individuals over time after having switched between sectors. However, while most turnovers result in benefits of workplace quality, a comparison of different types of sector turnover reveals that between-sector changes are more effective than within-sector changes.

Es ist eine weitverbreitete Ansicht, dass Nonprofit-Organisationen aufgrund ibrer ausgeprägten Zweck- und Werteorientierung Arbeitsbedingungen bieten, die überdurchschnittlich motivierend sind. Repräsentative empirische Belege auf Basis direkter Vergleiche liegen dazu allerdings bislang kaum vor. Diese Lücke versucht die vorliegende Studie auf der Grundlage von Längsschnittdaten zu schliessen. Ausgehend von der Selbstbestimmungstheorie und dem Konzept der Public Service Motivation wird untersucht, inwiefern sich die Wahrnehmung der Arbeitsbedingungen für Nonprofit-Organisationen von derjenigen in privat erwerbswirtschaftlichen oder öffentlich-rechtlichen Organisationen unterscheidet. Arbeitnehmerdaten des Schweizer Haushaltspanels zeigen, dass die Arbeit in NonprofitOrganisationen sich insbesondere in Bezug auf Aspekte der selbstbestimmten Arbeit abhebt. So beschreiben Arbeitnehmende im Nonprofit-Sektor ibre Arbeitsaufgaben als interessanter berichten eine höhere Arbeitszufriedenheit als ibre Kolleginnen und Kollegen im Wirtschafts- oder Verwaltungssektor. Die meisten Sektoreffekte zeigen sich auch im Längsschnitt, wenn Individuen den Arbeitssektor wechseln. Schliesslich zeigt der Vergleich verschiedener Arten von Sektorwechseln, dass Wechsel zwischen den Sektoren bezüglich der Verbesserung in den analysierten Variablen der Arbeitsplatzqualität effektiver sind als Wechsel innerhalb der Sektoren. 
Non-profit, job change, job satisfaction, task interest, mobility, career paths

Nonprofit, Arbeitsplatzwechsel, Arbeitszufriedenheit, Aufgabeninteresse, Karrierewege

\section{Introduction}

The relationship between working conditions and employee satisfaction is among the most intensively studied topic in human resource management research. In this context, researchers have also investigated whether the relevant working conditions differ significantly from sector to sector beyond the individual workplace: Is there any inter-sectoral variance that goes beyond the intra-sectoral variance of individual working conditions? Particular attention has been paid to the distinction of ownership structure: differences between public, private for-profit, and private non-profit organizations. Based on NorthAmerican data from 1977, Mirvis/Hacket (1983) found that working for non-profit organisations (NPO) such as voluntary organisations, associations, syndicates, foundations and cooperatives differs significantly from working for government organisations (GOs) or for-profit organisations (POs) in terms of job conditions and worker profiles. They state that working in the NPO sector is associated with lower wages, lower employment levels and a greater proportion of female workers. Moreover, with regard to perceived qualities of the workplace, the data suggest that NPO work is associated with more job autonomy, job effort and job satisfaction. These results concerning differences in job conditions and worker profiles have since been tested and confirmed for other countries (Vinokur-Kaplan 1996, Borzaga/Tortia 2006, Lanfranchi/Narcy 2008, De Cooman et al. 2011, Donegani et al. 2012, Becchetti et al. 2014, Lee 2016, Tohmo/Viinikainen 2017). However, the current debate lacks longitudinal evidence concerning the sector effects and their mediation.

Thus, the present study addresses the following questions. If NPO workers are more satisfied than PO workers, does a workplace change from a PO to an NPO increase job satisfaction? If so, does switching from an NPO to a PO decrease job satisfaction? Which type of sector turnover is the most effective in terms of workplace quality? Finally, if NPOs and POs would offer similar intrinsic rewards, then would NPO workers still be more satisfied than their PO counterparts?

\section{Self-determination theory and workplace quality}

Literature on NPOs often underlays the concept of the three-sector economy containing the market-oriented profit sector, the public sector and the non-profit sector (Weisbrod 1975). The main criteria for distinguishing the three sectors are the goal systems of the organisations, rather than the activities they engage in (von Schnurbein 2006). While private profit-maximizing firms embrace primarily profit-oriented goals, NPOs are mainly driven by mission-related objectives and GOs are shaped by political constitutions (Ben-Ner 1994; Quarter/Richmond 2001). As the following chapters will show, these different goal systems constitute, on a macro level, distinct labour markets and workplaces which affect, on a micro level, perceived workplace quality. Therefore, to explain differences in individuals' workplace ratings between the three sectors, we refer to the self-determination theory and link it with the construct of public service motivation.

In exploring the reasons for statistical differences between sector-specific working conditions, it is widely argued that the three sectors are associated with distinct patterns and 
mechanisms of worker motivation, both intrinsic and extrinsic motivation. Linked to these concepts are claims like 'NPO workers want to do something meaningful' or 'NPOs allow you to work with less competitive pressure' which suggest the existence and distinction of work drivers which come from within the individual and some which come from outside. Ryan/Deci (2000), thus, define intrinsic motivation as inherent drive that stems from the self and causes 'unalienated and authentic', self-determined actions. Deci (1992) argues, a person will be intrinsically motivated when there is an optimal match between the person and the activity. This match results from perceptions of autonomy, competence and relatedness. They not only increase intrinsic motivation but also allow extrinsic motivators to be internalized and become important to the individual's self (Deci 1992; Ryan/Deci 2000). Borzaga/Tortia (2006) state that for job satisfaction, intrinsic and relational attitudes, rather than attitudes motivated by economic interests, lead to an increase in job satisfaction. Moreover, individuals with internal motivation are more likely to attain goals, compared to individuals that are purely led by external influence (Godin et al. 2005).

We hypothesize that sectors and their organizations significantly differ in two of the three key factors of self-determination and, consequently, in the satisfaction of their employees (Table 1). There is no evidence that one may expect sectoral differences in the fit between individual competence beliefs and work requirements. Significant differences in autonomy and relatedness are to be expected and will be explored in the following sections.

\begin{tabular}{|l|c|c|c|c|}
\hline \multirow{2}{*}{ Sectors: } & \multicolumn{3}{|c|}{ Factors of self-determination } & \multirow{2}{*}{$\begin{array}{c}\text { Relative satis- } \\
\text { faction level }\end{array}$} \\
\cline { 2 - 4 } & Autonomy & Competence & Relatedness & lowest \\
\hline For-Profit Organizations & low & diverse & low & medium \\
\hline Public Organizations & low & diverse & high & highest \\
\hline Nonprofit Organizations & high & diverse & high & . \\
\hline
\end{tabular}

Table 1: Sector characteristics from a self-determination theory view (Deci 1992)

The concept of public service motivation (PSM) extends and specifies the relatedness factor in self-determination theory. PSM addresses what motivates people to work for public and non-profit organisations, thus, suggesting that public and non-profit work provide similar motivational incentives (Perry 2000). Perry (1996) measures PSM along six dimensions: attraction to commitment to the public interest, civic duty, social justice, self-sacrifice, compassion and public policy making. These aspects of PSM seem to be very similar to the motivational orientation of non-profit workers, as described in the literature. Francois $(2000,1)$ describes PSM as the drive that "inclines employees to provide effort out of concern for the impact of that effort on a valued social service". Thus, the similar goal system predicate of the two sectors results in similar intrinsic motivational bases on an individual level, which derives from the feeling of being connected to others, while caring for others and feeling cared (Homberg et al. 2015). Thus, we integrate PSM as a representation of relatedness.

While some studies speak of the non-profit sector being intrinsically motivating by giving employees the chance to do something worthwhile, make a difference to society, do something 'for work's sake' (Frey 1997; Light 2003), others call it moral motivation or intentions coming from personal normative beliefs (Frank 1996; Godin et al. 2005). 
Thereby, it is crucial that for non-profit workers, intrinsic aspects are more important than extrinsic motivators to the degree that intrinsic motivators, when they exist, can result in the acceptance of lower extrinsic rewards such as a negative wage differential (Leete 2000; Preston 1989).

\section{Sectoral differences in autonomy and relatedness}

Generally, differences in perceived job qualities and the resulting job satisfaction across the three sectors are, on the one hand, explained by focusing on different personal characteristics and related motivational concepts (De Cooman et al., 2011; Lee and Wilkins, 2011; Onyx and Maclean, 1996; Winter and Thaler, 2016). On the other hand, by examining factors that derive from the sector-specific work environment (LeRoux and Feeney, 2013; Kameräde and McKay, 2014; Lanfranchi and Narcy, 2008; Lewis and Frank 2002). Some authors highlight the interaction of both perspectives (e.g. Chen 2012; Vinokur-Kaplan 1996).

Differences in motivational mechanisms between NPO and GO workplaces result from different governance and goal systems that affect autonomy. Although both NPO and GO provide merit and collective goods, they are produced on behalf of different initiators and distributed to different groups. While GO are legitimized by law, are publicly financed, and are expected to distribute their goods evenly to affected populations, NPO are funded by sub-groups of the populations that share a certain interest, whereby their goods are distributed along more narrowly defined and self-selected segments of society (Lee/Wilkins 2011; Lipsky/Smith, 1989). These characteristics affect the organisation's goal system and result in distinct task characteristics and workplace environments. More specifically, public work actions are primarily a result of legislative imperatives, political compromises and collective interests that may exacerbate workers' internalization of regulations by thwarting their autonomy, which can reduce intrinsic motivation and can inhibit internalization of extrinsic motivation. Previous empirical research supports this view: NPOs distinguish themselves through a higher degree of self-government (Mirvis/Hacket 1983), flexible contracts, family-friendly policies and increased responsibility (Kameräde/McKay 2014; Lee/ Wilkins 2011), while public work is associated with higher levels of rule constraints, red tape and personal inflexibility (Chen 2012).

Motivational mechanisms in NPO and PO workplaces differ in both autonomy and relatedness. Profit orientation as a dominant concern of business organizations sets as much limits on a mission and public interest orientation as on the common values of cooperation, such as solidarity or cooperation. As a result, relatedness may not develop as well as it does in NPO or GO. Moreover, PO work may, in contrast with NPO work, be rather restricted in terms of autonomy because of competitive pressure. Indeed, as studies show, NPO seem to prevail over PO in terms of autonomy, influence and responsibility (Lanfranchi/Narcy 2008; Mirvis/Hacket 1983).

Based on the theoretical considerations and previous empirical findings, we therefore assume the following hypothesis: On average, job satisfaction in NPO is higher than in GO, and job satisfaction in both NPO and GO is higher than in PO. 


\section{Data and measures}

The main data basis of the study is the Swiss Household Panel (SHP) administered by the Swiss Centre of Expertise in the Social Sciences (FORS) in 16 waves from 1999 to 2014. ${ }^{1}$ It conducted yearly interviews of individuals about several areas of life, including their current main job. For all analyses, individuals who were self-employed, employees who worked in an apprenticeship or training contract or worked voluntarily, handicapped people working in a protected atelier or/and were under the age of 20 were excluded from the sample. Furthermore, employees who worked less than eight hours per week in their main job, earned below $900 \mathrm{CHF}$ or more than 20,000 CHF per month and employees who were engaged in more than two jobs beside the current main job were excluded. To maintain the sample size, the latter wage and workload restrictions were dropped for the turnover analyses since the wage and work-hour effects seemed to be rather robust to changes in sample restrictions.

The SHP does not include questions on the non-profit nature of the employer. To overcome this, the panel was linked with data from the Swiss Federal Statistical Office to determine whether an individual worked for a PO, an NPO or a GO. Crucial in determining sector affiliation was information regarding the industry (NOGA 2002), the legal structure of the organisation as well as individuals' answers to the question on whether the employer was a public one or not, which was the only variable addressing the economic nature of the sector directly. The non-profit sample thereby included individuals whose main employers either were associations which engaged in an NPO-typical branch ${ }^{2}$ or were cooperatives or foundations which were reported as private employers and engaged in an NPO-typical branch. The for-profit sample included individuals whose main employers were stock companies $(\mathrm{AG})$ or limited liability companies $(\mathrm{GmbH})$ that were not engaged in a $\mathrm{GO}$-exclusive branch ${ }^{3}$ and were not reported as public employers. The government sample included individuals whose main employers were declared as organisations under public law by the referring legal form, individuals whose main employers were reported as public (individuals' answers) and were not declared as associations, and individuals whose main employers engaged in a GO-exclusive industry. The sector variable and corresponding types of turnovers were applied as categorical variables.

Apart from the variable indicating the sector of the specific employers, the regression models included variables on sex, age, Swiss nationality, marital status ( 5 categories), education (9 categories based on the International Standard Classification of Education ISCED-1997), profession (15 categories based on the International Standard Classification of Occupations ISCO-88), hourly wage, number of contractual hours per week, health status, general life satisfaction, region ( 7 categories), company size ( 9 categories) and year.

Dependent variables are single-item measurements. Both, satisfaction with interest in tasks as well as job satisfaction are measured on a 11-point scale ranging from $0=$ not at

1 For some analyses, the sample has been narrowed because of missing information in some years (see declaration in the specific table).

2 As NPO-typical but not NPO-exclusive branches were considered: schools, kindergartens (NOGA 2002 section M) hospitals, medical offices, social institutions (NOGA 2002 section N) advocacy (NOGA 2002 section 91), culture and sports (NOGA 2002 section 92 and some of 93).

3 As GO-exclusive branches were considered: public administration (NOGA section L) and extraterritorial organisations such as consulates (NOGA 2002 section Q). 
all satisfied to $10=$ completely satisfied . The single-item measurement of job satisfaction thereby is, in general, considered to be reliable and valid (Dolbier et al. 2004).

For the variables determining the sector affiliation of employers as well as for the control variables (i.e. profession, organisation size and work hours), missing values due to filter errors, declined answers and lack of knowledge were longitudinally imputed. Therefore, if there was no change of employer, then these missing values were substituted using the specific individuals' past/future survey data. In the case of imputable contractual work hours, additional data from the variable specifying the workload as either full-time or part-time (with the corresponding contractual percentage) was used to calculate the missing hours, based on a typical, full-time 42-hour work week. In the case of wages, distributed imputed income data from FORS was used, upon which the hourly wage was calculated.

Because the wage statement in the SHP does not explicitly refer to the current main job only, it could have been biased for employees that had multiple employment contracts. Therefore, although this affects at most 10 per cent of the employees $(\mathrm{N}=2014)$, for those who claimed to have more than one job, the statistical models include a corresponding interaction term. That the terms are not significant at the 5 per cent significance level implies that there is no substantial bias in the wage term. Moreover, as a robustness check, we assessed relationships within a reduced sample, containing only individuals engaging in one job, which showed that the wage effects were robust even within this reduced sample.

\section{Analytical procedures}

Since previous studies offer only limited statistical insights about how sector effects on workplace quality are manifesting in the longitudinal view, our analyses exploited the panel structure of the data. Thereby, to assess the effects of sector affiliation on satisfaction with interest in tasks, participation and job satisfaction in a holistic manner, the analysis followed a three-step approach, which will also serve to present the results later on.

In a first step, which ignores the panel structure, we used pooled OLS models with cluster-robust standard errors (to adjust for repeated measurements of the same individuals) while the sector effects are displayed in contrast to the other two sectors separately. While the resulting differences in the pooled OLS models could indeed be an effect of sector-specific work and the work environment, the differences could also be ascribed to sector-independent personal characteristics. Therefore, in a second step, we applied fixed-effects (FE) models to control for individual-specific characteristics (see Table 2).

However, with this second step, the actual effects of different types of sector movements are not yet clear. Therefore, in a third step, the entire sample was scanned for individuals changing the employer whereby nine types of between-sector or within-sector movements involving the three sectors as left or/and entered sector. From each turnover, the difference between the before-turnover rating and the after-turnover rating was used as a dependent variable which was regressed on the turnover categories and the potential changes in the control variables. ${ }^{4}$

It is widely known that turnover can be affected by the so-called honeymoon-hangover effect, which describes the phenomenon of an immediate increase in ratings related to workplace quality after turnover, which is then followed by a decrease (Boswell et al. 2009).

4 For some variables with no or relatively low within-variance (e.g. sex), the after-turnover values were included in the model instead of the difference (as indicated in Table 3). 
To even out such an eventual effect, the before-change and after-change values were calculated by averaging the respective values of the two years before and after the individual's turnover, whenever more data prior and subsequent to the turnover was available. This procedure was also applied to the changes in the control variables. To compare the effects of all of the turnover types, OLS models (with cluster-robust standard errors) were used (see Table 3).

\section{Results}

Table 2 shows the results of the pooled and fixed-effects regressions that assess sectoral differences in satisfaction. The pooled OLS model for satisfaction with interest in task indicates that compared with PO work, NPO work is associated with a 0.3 -point higher rating, and GO work is associated with a 0.16-point higher rating in task-interest satisfaction. Compared with GO work, NPO work is also associated with a higher rating but on a lower significance level. Accounting for individual-specific effects, the results of the fixed-effects regressions indicate that individuals who experience both PO and NPO work have, on average, a 0.4-point higher satisfaction with interest in tasks when they are working for an NPO. Furthermore, the data suggest that people who experience both PO and GO work exhibit, on average a 0.2-point higher rating in task-interest satisfaction when they work in the public sector. Moreover, people who experience both NPO and GO work report a 0.2-point higher rating in task-interest satisfaction.

\begin{tabular}{|c|c|c|c|c|c|}
\hline & & \multicolumn{2}{|c|}{$\begin{array}{l}\text { Satisfaction with interest in tasks } \\
(0=\text { not at all satisfied; } \\
10=\text { completely satisfied })\end{array}$} & \multicolumn{2}{|c|}{$\begin{array}{l}\text { Satisfaction with job in general } \\
\qquad \begin{array}{l}(0=\text { not at all satisfied; } \\
10=\text { completely satisfied })\end{array}\end{array}$} \\
\hline \multicolumn{2}{|l|}{ Variable } & Pooled OLS & $\begin{array}{c}\text { OLS } \\
\text { (fixed effects) }\end{array}$ & Pooled OLS & $\begin{array}{c}\text { OLS } \\
\text { (fixed effects) }\end{array}$ \\
\hline For-profit employee (PO) & \multirow{2}{*}{$\begin{array}{l}\text { Ref.: } \\
\text { Nonprofit } \\
\text { employee } \\
\text { (NPO) }\end{array}$} & $\begin{array}{c}-0.307 * * * \\
(0.079)\end{array}$ & $\begin{array}{c}-0.403 * * \\
(0.127)\end{array}$ & $\begin{array}{c}-0.175 * \\
(0.038)\end{array}$ & $\begin{array}{c}-0.398 * * * \\
(0.093)\end{array}$ \\
\hline Public employee (GO) & & $\begin{array}{c}-0.143(*) \\
(0.074)\end{array}$ & $\begin{array}{c}-0.178(*) \\
(0.101)\end{array}$ & $\begin{array}{l}-0.061 \\
(0.057)\end{array}$ & $\begin{array}{c}-0.152(*) \\
(0.080)\end{array}$ \\
\hline \multicolumn{2}{|l|}{ Hourly wage (ln) } & $\begin{array}{c}0.280 * * * \\
(0.066)\end{array}$ & $\begin{array}{c}0.099 \\
(0.082)\end{array}$ & $\begin{array}{c}0.068 \\
(0.051)\end{array}$ & $\begin{array}{c}0.028 \\
(0.062)\end{array}$ \\
\hline \multicolumn{2}{|c|}{ Hourly wage $(\ln ) *$ only one job } & $\begin{array}{l}-0.005 \\
(0.017)\end{array}$ & $\begin{array}{c}0.009 \\
(0.018)\end{array}$ & $\begin{array}{l}-0.020 \\
(0.014)\end{array}$ & $\begin{array}{l}-0.014 \\
(0.016)\end{array}$ \\
\hline \multicolumn{2}{|c|}{ Contractual hours per week (ln) } & $\begin{array}{c}0.657 * * * \\
(0.061)\end{array}$ & $\begin{array}{c}0.362 * * * \\
(0.100)\end{array}$ & $\begin{array}{l}0.104 * \\
(0.048)\end{array}$ & $\begin{array}{l}-0.051 \\
(0.079)\end{array}$ \\
\hline \multicolumn{2}{|l|}{ No. of observations } & 19,594 & 19,594 & 19,595 & 19,595 \\
\hline \multicolumn{2}{|l|}{ No. of individuals } & 6,333 & 6,333 & 6,333 & 6,333 \\
\hline \multicolumn{2}{|l|}{ Time period } & $2008-2014$ & $2008-2014$ & $2008-2014$ & $2008-2014$ \\
\hline \multicolumn{2}{|l|}{$\mathrm{F}$} & $16.31 * * *$ & $3.88 * * *$ & $20.03 * *$ & $6.07 * * *$ \\
\hline \multicolumn{6}{|c|}{$\begin{array}{l}\text { Notes: Weighted regressions. Robust standard errors in parentheses (corrected for repeated observations } \\
\text { of individuals). Significance levels: }(*) \mathrm{p}<0.10 ; * \mathrm{p}<0.05 ; * * \mathrm{p}<0.01 ; * * \mathrm{p}<0.001 \text {. Variables not } \\
\text { shown, but included in the models: sex, age, age }{ }^{2} \text {, first nationality: Swiss, marital status ( } 5 \text { categories), } \\
\text { education ( } 8 \text { categories), satisfaction with life in general, health status, profession ( } 15 \text { categories), region } \\
\text { ( } 7 \text { categories), company size ( } 9 \text { categories) and year dummies ( } 7 \text { categories). Source: Swiss Household } \\
\text { Panel (SHP) / Federal Statistical Office (FSO). }\end{array}$} \\
\hline
\end{tabular}

Table 2: Sector effects on satisfaction with interest in tasks respectively job in general 
For general job satisfaction, both models (pooled and fixed-effects) suggest that workers are more satisfied when they are employed by a non-profit or a public employer. A significant difference in job satisfaction was observed between NPO and GO affiliation in the fixed-effects regression only.

A more nuanced methodological approach focusing on specific types of job changes should additionally clarify sectoral effects on workplace-quality variables (analysis step 3). With the aforementioned restrictions, up to 1,524 cases of turnover were used to assess differences between before-turnover ratings and after-turnover ratings (see table 3 for sizes of subsamples and before-turnover and after-turnover ratings).

Figure 1 shows the change in satisfaction with interest in tasks and general job satisfaction with different types of turnover. The results of a paired sample t-test indicate a significant increase in satisfaction with interest in tasks and job satisfaction over all types of turnover (of 0.3 points). This suggests that workplace quality variables generally increase with most types of sector turnover. Nonetheless, the data imply that changes in ratings differ with various sorts of sector turnover. Thus, before- and after-turnover ratings (not displayed) seem to vary significantly with different movements. When looking at satisfaction with interest in tasks, changing either from a PO to an NPO or changing from a PO to a GO seems to result in rather large increases in satisfaction with interest in tasks of 1.1 and 0.8 points, respectively, because people arriving from the for-profit sector have, on average, a relatively low initial rating $(M=6.87$ and $M=7.17$, respectively). In contrast, the data indicate that non-profit employees moving to other non-profit employers already had a high interest in tasks before the change $(M=8.51)$ and the turnover did not increase that interest, on average. This also suggests that NPO employees are less likely to change their employers because of less interesting tasks. Moreover, it appears that while a switch from a PO to an NPO provides more interesting tasks, the other way around (switching from an NPO to a PO) does not. With regard to general job satisfaction, the increase in ratings is highest when changing from a $\mathrm{PO}$ to a GO and, remarkably, is also relatively

Average increases of satisfaction with interest in tasks $(0=$ not at all satisfied; $10=$ completely satisfied $)$

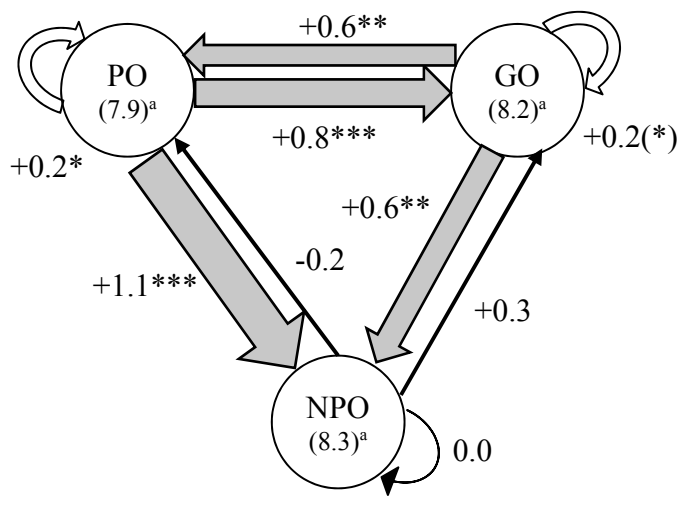

Average Increase of satisfaction with interest in tasks with all sorts of turnover: $+0.3 * * *$
Average increases of satisfaction with job in general $(0=$ not at all satisfied; $10=$ completely satisfied $)$

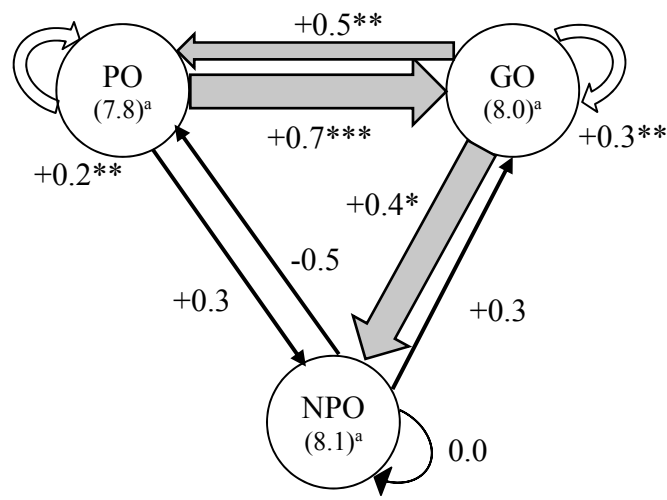

Average Increase of satisfaction with job in general with all sorts of turnover: $+0.3 * * *$

Notes: $\left({ }^{*}\right) \mathrm{p}<0.1 ; * \mathrm{p}<0.05 ; * \mathrm{p}<0.01 ; * * \mathrm{p}<0.001$. Source: Swiss Household Panel (SHP) / Federal Statistical Office (FSO). ${ }^{a}=$ average weighted ratings of employees in the specific sector in 2014

Figure 1: Types of turnover and related changes in job quality variables (unweighted) 
high when changing from a GO to a PO. NPO leavers, on average, do not experience increased job satisfaction with any turnover option, unlike in the case of task-interest satisfaction.

However, to evaluate the implications of these before-after turnover differences in a multivariate context and to determine whether these changes differ statistically across the types of turnover, we regressed them on nine turnover dummies (see Table 3; ' + ' and '-' refer to a stronger and weaker effect in comparison with the reference turnover, respectively). This finally leads to the conclusion that some movement types affect variables of perceived job qualities more strongly than others.

\begin{tabular}{|c|c|c|c|c|}
\hline & & & $\begin{array}{c}\text { Change in satisfaction with } \\
\text { interest in tasks } \\
(0=\text { not at all satisfied } / \\
10=\text { completely satisfied })\end{array}$ & $\begin{array}{c}\text { Change in satisfaction with } \\
\text { job in general } \\
(0=\text { not at all satisfied } / \\
10=\text { completely satisfied })\end{array}$ \\
\hline \multirow{3}{*}{$\begin{array}{l}\text { moving from } \\
\text { PO }\end{array}$} & to $\mathrm{PO}$ & $\mathrm{N}=503$ & Ref. & Ref. \\
\hline & to GO & $\mathrm{N}=130$ & $+*$ & $+*$ \\
\hline & to NPO & $\mathrm{N}=45$ & $+*$ & - \\
\hline \multirow{3}{*}{$\begin{array}{l}\text { moving from } \\
\text { GO }\end{array}$} & to $\mathrm{GO}$ & $\mathrm{N}=509$ & Ref. & Ref. \\
\hline & to $\mathrm{PO}$ & $\mathrm{N}=144$ & + & + \\
\hline & to NPO & $\mathrm{N}=83$ & $+*$ & + \\
\hline \multirow{3}{*}{$\begin{array}{l}\text { moving from } \\
\text { NPO }\end{array}$} & to NPO & $\mathrm{N}=41$ & Ref. & Ref. \\
\hline & to $\mathrm{PO}$ & $\mathrm{N}=21$ & - & - \\
\hline & to $\mathrm{GO}$ & $\mathrm{N}=48$ & + & + \\
\hline \multicolumn{3}{|c|}{ Control variables } & & \\
\hline \multicolumn{3}{|c|}{$\Delta$ hourly wage $(\ln )$} & 0.110 & 0.126 \\
\hline \multicolumn{3}{|c|}{$\Delta$ hourly wage $(\ln ) * \Delta$ number of jobs } & -0.042 & 0.015 \\
\hline \multicolumn{3}{|c|}{$\Delta$ contractual hours per week $(\ln )$} & $0.475 * *$ & -0.020 \\
\hline \multicolumn{3}{|c|}{$\Delta$ company size } & $-0.046(*)$ & -0.021 \\
\hline \multicolumn{3}{|c|}{ No. of observations } & 1,137 & 1,137 \\
\hline \multicolumn{3}{|c|}{ No. of individuals } & 916 & 916 \\
\hline \multicolumn{3}{|l|}{ Time period } & 2004-2014 & 2004-2014 \\
\hline \multicolumn{3}{|l|}{$\mathrm{F}$} & $2.52 * * *$ & $2.34 * * *$ \\
\hline \multicolumn{5}{|c|}{$\begin{array}{l}\text { Notes: Unweighted OLS regressions with robust standard errors (corrected for repeated observations of } \\
\text { individuals). Not shown in the table but additionally included in the models are changes in profession, } \\
\text { changes in general life satisfaction and health status as well as the after-turnover values of sex, age, mari- } \\
\text { tal status, education, first nationality, region (language) and years. Significance levels: }{ }^{*} \text { ) } p<0,10 ; * \\
\text { p }<0,05 ; * * p<0,01 ; * * * p<0,001 ; \downarrow=\text { reading direction; Ref. = reference switch. Source: Swiss House- } \\
\text { hold Panel (SHP) / Bundesamt für Statistik (BFS). }\end{array}$} \\
\hline
\end{tabular}

Table 3: Types of turnover and related changes in perceived job qualities 
What seems most pragmatic is to explore turnover types where employees leave the same sector to compare potential turnover options for an average sector employee. Looking at PO leavers, they are, on average, more likely to perceive more interesting tasks when they change to either an NPO or a GO rather than when they change to another PO, whereas the perceived interest surplus when changing to an NPO seems slightly higher than changing to a GO, although the difference is not significant. Moreover, when people leave a $\mathrm{GO}$, it seems that they perceive a greater increase in satisfaction with interest in tasks when they change to either an NPO or a PO rather than when they stay in the public sector, although the latter effect does not significantly differ. Although the difference is not significant, it appears that leaving to join an NPO is associated with a greater change in task interest than leaving to join a PO. When people leave the non-profit sector, there is nothing in the data to suggest that either turnover option is more effective in terms of interest in tasks.

Looking at the comparison of job satisfaction derived from different types of sector turnover, the data imply that people changing from a PO to an NPO do not perceive a higher or lower impact on job satisfaction than people staying in the sector, but changing to a GO increases job satisfaction significantly more than staying in the sector or changing to an NPO. Statistically, employees who leave the public sector do not experience a significantly higher or lower change with either turnover option. Employees who leave a nonprofit workplace have neither a significantly increased nor a decreased benefit with either option.

Given that the non-profit sector is rather small by nature (and that our captured sample was also small in terms of NPO involvement as either former or follow-up employer), a limitation of this study is the inherent difficulties in establishing significant effects in inferential contexts, compared with if a larger such sample had been available. Another limitation of the study concerns a crucial variable to determine whether an individual is working for either a private or a public firm, as provided by the interviewees: it appears that they are not always sure if their employer should be considered as public or not.

\section{Conclusion and implications}

The findings have important implications for sector-specific HRM and employer branding. The NPO benefits concerning interesting tasks and job satisfaction, of course, should be used as persuasive arguments in recruitment, which can be even more efficiently communicated when NPOs realize their position within the labour market and individuals' careers; the average NPO employee is 46 years old and highly educated, and a change from a PO to an NPO is twice as common as the other way around. Thus, on the one hand, NPO workplaces could be conceptualized and communicated as the highlight of one's career, as doing something worthwhile, as finally doing something that makes one happy after having ensured economic well-being by working in other sectors. On the other hand, in the light of the principal-agent problem, the mission-driven work atmosphere and lowcontrol work environment could eventually benefit agent shirking while still resulting in high general job satisfaction. Thus, NPO managers should provide a balanced mix of intrinsic and extrinsic incentives to sustain both job satisfaction and performance on a high level. Finally, NPO managers must be aware that the sector-specific job satisfaction benefit may be endangered once intrinsic task aspects are missing. This suggests that other im- 
portant working condition at NPO workplaces, especially extrinsic aspects, should be created to attract workers of diverse motivational orientation and skill profiles.

Similar to NPO managers, GO managers should attract PO workers by promoting the interesting tasks associated with the public sector. However, HR managers at GO should reduce red tape and increase worker participation to foster workers self-determination and retain leadership capabilities. After all, this is suggested by the finding that switching from a GO workplace to a NPO workplace results in a bigger increase in participation than switching to workplaces of the other sectors.

While our findings suggest that PO do not have a major advantage attracting workers by intrinsic incentives, PO recruiters may attract workers with significant other (extrinsic) benefits leading to job satisfaction increases, especially when former GO workers are targeted. However, since the for-profit sector does not inherently benefit from PSM, PO managers should compensate by allowing for more relatedness, autonomy and competence leading to more self-determined work motivation.

\section{References}

Becchetti, L./Castriota, S./Depedri, S. (2014): Working in the for-profit versus not-for-profit sector: What difference does it make? An inquiry on preferences of voluntary and involuntary movers, in: Industrial and Corporate Change, Vol. 23, No. 4, pp. 1087-1120.

Ben-Ner, A. (1994): Who benefits from the nonprofit sector? Reforming law and public policy towards nonprofit organizations, in: Yale Law Journal, Vol. 104, No. 3 pp. 731-762.

Borzaga, C./Tortia, E. (2006): Worker motivations, job satisfaction, and loyalty in public and nonprofit social services, in: Nonprofit and Voluntary Sector Quarterly, Vol. 35, No. 2, pp. 225248.

Boswell, W. R./Shipp, A. J./Payne, S. C./Culbertson, S. S. (2009): Changes in newcomer job satisfaction over time: Examining the pattern of honeymoons and hangovers, in: Journal of Applied Psychology, Vol. 94, No. 4, pp. 844-858.

Chen, C. A. (2012): Explaining the difference of work attitudes between public and nonprofit managers: The views of rule constraints and motivation styles, in: American Review of Public Administration, Vol. 42, No. 4, pp. 437-460.

De Cooman, R./De Gieter, S./Pepermans, R./Jegers, M. (2011): A cross-sector comparison of motivation-related concepts in for-profit and not-for-profit service organizations, in: Nonprofit and Voluntary Sector Quarterly, Vol 40, No. 2, pp. 296-317.

Deci, E. L. (1992): The relation of interest to the motivation of behavior: A self-determination theory perspective, in: Renninger, K. A., Hidi, S./Krapp, A. (Eds.), The role of interest in learning and development. Psychology Press, pp. 43-70.

Dolbier, C. L./Webster, J. A./McCalister, K. T./Mallon, M. W./Steinhardt, M. A. (2005): Reliability and validity of a single-item measure of job satisfaction, in: American Journal of Health Promotion, Vol. 19, No. 3, pp. 194-198.

Donegani, C. P./McKay, S./Moro, D. (2012): A dimming of the "warm glow"? Are non-profit workers in the UK still more satisfied with their jobs than other workers?, in: Advances in the Economic Analysis of Participatory/Labor-Managed Firms, Vol. 13, pp. 313-342.

Francois, P. (2000): 'Public service motivation' as an argument for government provision, in: Journal of Public Economics, Vol. 78, No. 3, pp. 275-299. 
Frank, R. H. (1996): What price the moral high ground?, in: Southern Economic Journal, Vol. 63, No. 1, pp. 1-17.

Frey, B. S. (1997): On the relationship between intrinsic and extrinsic work motivation, in: International Journal of Industrial Organization, Vol. 15, No. 4, pp. 427-439.

Godin, G./Conner, M./Sheeran, P. (2005): Bridging the intention-behaviour gap: The role of moral norm, in: British Journal of Social Psychology, Vol. 44, No. 4, pp. 497-512.

Homberg, F./McCarthy, D./Tabvuma, V. (2015): A meta-analysis of the relationship between public service motivation and job satisfaction, in: Public Administration Review, Vol. 75, No. 5, pp. 711-722.

Kameräde, D./McKay, S. (2015): Is there a subjective well-being premium in voluntary sector employment?, in: Voluntas, Vol. 26, No. 6, pp. 2733-2754.

Lanfranchi, J./Narcy, M. (2008): Différence de satisfaction dans l'emploi entre secteurs à but lucratif et à but non lucratif: le rôle joué par les caractéristiques d'emploi, in: Annals of Public and Cooperative Economics, Vol. 79, No. 2, pp. 323-368.

LeRoux, K./Feeny, M. K. (2013): Factors attracting individuals to nonprofit management over public and private sector management, in: Nonprofit Management \& Leadership, Vol. 24, No. 1, pp. 43-62.

Lee, Y. (2016): Comparison of job satisfaction between nonprofit and public employees, in: Nonprofit and Voluntary Sector Quarterly, Vol. 45, No. 2, pp. 295-313.

Lee, Y./Wilkins, V. M. (2011): More similarities or more differences? Comparing public and nonprofit managers' job motivations, in: Public Administration Review, Vol. 71, No. 1, pp. 45-56.

Leete, L. (2000): Wage equity and employee motivation in nonprofit and for-profit organizations, in: Journal of Economic Behavior/Organization, Vol. 43, No. 4, pp. 423-446.

Lewis, G. B./Frank, S. A. (2002). Who wants to work for the government?, in: Public Administration Review, Vol. 62, No. 4, pp. 395-404.

Light, P. C. (2003): The health of the human services workforce. Center for Public Service, Brookings Institution.

Lipsky, M./Smith, S. (1989): Nonprofit organizations, government, and the welfare state, in: Political Science Quarterly, Vol. 104, No. 4, pp. 625-648.

Miller, K./Monge, P. (1986): Participation, satisfaction, and productivity: A meta-analytic review, in: Academy of Management Journal, Vol. 29, No. 4, pp. 727-753.

Mirvis, P. H./Hackett, E. J. (1983): Work and work force characteristics in the nonprofit sector, in: Monthly Labor Review, Vol. 106, No. 4, pp. 3-12.

Onyx, J./Maclean, M. (1996): Careers in the third sector, in: Nonprofit Management \& Leadership, Vol. 6, No. 4, 331-345.

Perry, J. L. (1996): Measuring public service motivation: An assessment of construct reliability and validity, in: Journal of Public Administration Research and Theory, Vol. 6, No. 1, pp. 5-22.

Perry, J. L. (2000): Bringing society in: Toward a theory of public-service motivation, in: Journal of Public Administration Research and Theory, Vol. 10, No. 2, pp. 471-488.

Preston, A. E. (1989): The nonprofit worker in a for-profit world, in: Journal of Labor Economics, 7, No. 4, pp. 438-463.

Quarter, J./Richmond, B. J. (2001): Accounting for social value in nonprofits and for-profits, in: Nonprofit Management \& Leadership, Vol. 12, No. 2, pp. 75-85. 
Renninger, K. A. (2000): Individual interest and its implications for understanding intrinsic motivation, in: Sansone, C./Harackiewicz, J. M. (Eds.), Intrinsic and extrinsic motivation: The search for optimal motivation and performance, pp. 373-404. San Diego, CA.

Ryan, R. M./Deci, E. L. (2000): Self-determination theory and the facilitation of intrinsic motivation, social development, and well-being, in: American Psychologist, Vol. 55, pp. 68-78.

Tohmo, T./Viinikainen, J. (2017): Does intersectoral labour mobility pay for academics?, in: Scientometrics, Vol. 113, No. 1, pp. 83-103.

Vinokur-Kaplan, D. (1996): Workplace attitudes, experiences, and job satisfaction of social work administrators in nonprofit and public agencies: 1981 and 1989, in: Nonprofit and Voluntary Sector Quarterly, Vol. 25, No. 1, pp. 89-109.

von Schnurbein, G. (2006): Bestandesaufnahme zum Dritten Sektor der Schweiz, in: Verbands-Management, Vol. 32, No. 1, pp. 32-37.

Weisbrod, B. A. (1975): Toward a theory of the voluntary non-profit sector in a three sector economy, in: Phelps, E. (Ed.), Altruism, morality and economic theory, pp. 171-96. New York.

Winter, V./Thaler, J. (2015): Does motivation matter for employer choices? A discrete-choice analysis of medical students' decisions among public, nonprofit, and for-profit hospitals, in: Nonprofit and Voluntary Sector Quarterly, Vol. 45, No. 4, pp. 762-786.

Remo Aeschbacher, PhD, researcher of competitive workplace conditions, is an Employer Brand Manager at Credit Suisse AG.

Address: Remo Aeschbacher, Aarbergstrasse 52, 3294 Büren an der Aare, Email: remo.aeschbacher@gmx.ch

Markus Gmür, Prof. Dr., heads the Chair for Nonprofit Management at the University of Fribourg in Switzerland.

Address: Verbandsmanagement Institut (VMI), Universität Freiburg, Bd de Pérolles 90, CH-1700 Freiburg, Phone: +41 (0) 2630084 00, Email: markus.gmuer@unifr.ch

Acknowledgement:

This study has been realised using the data collected by the Swiss Household Panel (SHP), which is based at the Swiss Centre of Expertise in the Social Sciences FORS. The project is financed by the Swiss National Science Foundation. 